\title{
FAKTOR-FAKTOR YANG MEMPENGARUHI KEPUASAN KEUANGAN MAHASISWA/I UNIVERSITAS TARUMANAGARA
}

\author{
Preshella Sulistio dan Hendra Wiyanto \\ Program Studi Manajemen, Fakultas Ekonomi dan Bisnis \\ Universitas Tarumanagara, Jakarta \\ < preshella.115170044@stu.untar.ac.id, hendraw@fe.untar.ac.id >
}

\begin{abstract}
The purpose of this research is to analysis effect of Financial Knowledge, Financial Efficacy and Childhood Consumer Experience toward Financial Satisfaction on students of Tarumanagara University. Samples of this research where selected by non probability method with purposive technique sampling. The sample of this research using 150 respondents. The data collection technique was carried out using a questionnaire. Data were analyzed using SEM-PLS method with Smart PLS 3.3.3 application. The results of this study indicate that Financial Knowledge did not have a significant effect of Financial Satisfaction. Meanwhile, Financial Efficacy and Childhood Consumer Experience have a significant effect of Financial Satisfaction.
\end{abstract}

Keywords: Financial Knowledge, Financial Efficacy, Childhood Consumer Experience, Financial Satisfaction

Abstrak: Penelitian ini bertujuan untuk mengetahui pengaruh pengetahuan keuangan, efikasi keuangan, dan pengalaman anak terhadap kepuasan keuangan pada Mahasiswa/i Universitas Tarumanagara. Pengumpulan sampel dilakukan dengan menggunakan metode nonprobability dengan menggunakan teknik purposive sampling. Sampel dari penelitian ini menggunakan sebanyak 150 responden. Teknik pengambilan data dilakukan dengan menggunakan kuesioner melalui google form. Data dianalisis menggunakan metode SEMPLS dengan aplikasi Smart PLS 3.3.3. Hasil yang didapatkan dari penelitian ini adalah Pengetahuan Keuangan tidak memiliki pengaruh signifikan terhadap Kepuasan Keuangan. Sedangkan Efikasi Keuangan dan Pengalaman Anak memiliki pengaruh signifikan terhadap Kepuasan Keuangan.

Kata kunci: Pengetahuan Keuangan, Efikasi Keuangan, Pengalaman Anak, Kepuasan Keuangan

\section{LATAR BELAKANG}

Menurut Hira dan Mugenda (1998) kepuasan hidup seorang individu dapat diupayakan dengan melakukan perubahan cara mengelola uang secara tepat. Pembentukan rencana keuangan yang tepat dapat mendorong kesejahteraan keuangan dimana sebagai indikasi kepuasan seorang individu serta membentuk pola pengelolaan pengeluaran dan pendapatan. Kesejahteraan pada setiap individu tentunya berbeda dan dapat disesuaikan dengan standar keuangan yang dimiliki. Pengelolaan dalam perencanaan keuangan dapat melalui penghasilan yang diperoleh secara rutin dimana disesuaikan dengan kebutuhan saat ini / kebutuhan rutin dan kebutuhan masa depan untuk mencapai kepuasan keuangan. Financial Satisfaction telah menjadi perhatian global yang sangat penting. Salah satunya di wilayah DKI Jakarta ditemukan banyaknya individu yang belum dapat memperlakukan keuangan dengan baik 
terutama bagi mahasiswa yang hidup mandiri. Terdapat masalah keuangan pada mahasiswa dapat berdampak pada kepuasan keuangannya seperti ketidakmampuan untuk memenuhi kebutuhan, kurangnya simpanan untuk masa depan serta menjadi salah satu faktor berhentinya mahasiswa untuk berkuliah yang biasanya disebabkan oleh tidak mampu dalam membayar uang kuliah.

Sabri et al. (2008) menyatakan dalam penelitiannya bahwa pengetahuan keuangan yang dilakukan pada mahasiswa masih relatif rendah. Oleh karena itu, diperlukan financial knowledge yang memadai agar terhindar dari masalah keuangan. Pengetahuan keuangan memberi pengetahuan yang membuat individu mengerti atas apa, bagaimana, mengapa, dimana, dan kapan dalam menentukan penggunaan uang. Individu dengan mempunyai pengetahuan keuangan, maka akan memilih produk keuangan dengan biaya yang lebih rendah dan kualitas kredit yang lebih baik untuk memenuhi kebutuhan dan keinginan individu sehingga dapat memiliki rasa puas atas kondisi keuangannya (Arifin, 2018).

Selain financial knowledge untuk mencapai kepuasan keuangan pada mahasiswa diperlukan adanya tingkat kemampuan mengenai keuangan. Individu yang memiliki kemampuan untuk mengelola keuangan dengan tepat, maka mempunyai kemungkinan untuk memperoleh masalah keuangan di masa depan. Hal itulah yang menjadi kajian masalah dari penelitian ini yaitu dengan menggunakan financial efficacy sebagai prediktor kepuasan keuangan. Dalam penelitian ini self-efficacy dapat dihubungkan dengan financial efficacy yang dapat didefinisikan sebagai keyakinan atas kemampuan diri dalam bidang keuangan untuk melakukan perubahan mencapai kepuasan yang diinginkan.

Menurut Sabri et al. (2008) sebagian besar mahasiswa pada saat berada di Universitas baru pertama kali memiliki pengalaman untuk mengelola keuangannya sendiri tanpa adanya pengawasan dari orang tua. Financial Satisfaction ditentukan oleh kesadaran berupa pengalaman (Hira dan Mugenda, 1998). Mahasiswa yang mengalami berbagai masalah keuangan biasanya ditimbulkan karena adanya biaya kebutuhan yang semakin tinggi, menurunnya kegiatan menabung, belum memiliki pendapatan pribadi, serta kurangnya pengalaman yang diberikan oleh orang tua sejak dini. Oleh sebab itu, tantangan bagi orang tua saat ini adalah bagaimana cara orang tua mengajarkan anak dalam mengelola keuangan dengan baik untuk dapat mencapai kepuasan keuangan yang diinginkan.

Penelitian ini juga memberikan manfaat dimana secara praktis, diharapkan dapat membantu untuk meningkatkan financial satisfaction dengan memahami financial knowledge, financial efficacy, dan childhood consumer experience terutama di kalangan mahasiswa/i. Kemudian secara akademis, diharapkan dapat menambah wawasan untuk pengembangan ilmu pengetahuan terutama dalam bidang manajemen keuangan serta dapat dijadikan referensi dalam melakukan penelitian selanjutnya mengenai financial knowledge, financial efficacy, childhood consumer experience dan financial satisfaction.

\section{Gambaran Umum Teori Subjective Well Being Theory (SWB)}

Hubungan antara pendapatan dan kebahagiaan individu merupakan salah satu mata pelajaran yang paling dibahas dalam literatur mengenai kesejahteraan subjektif (SWB) sejak awal pada tahun 1970-an. Menurut penelitian Adrian G. White (2007) mengenai subjective well-being (SWB) menyatakan bahwa diperlukan adanya upaya untuk mengukur subjective well-being (SWB) dengan menggunakan beberapa faktor sebagai tolak ukur. Beberapa faktor terkuat yang mempengaruhi SWB adalah kesehatan, kekayaan, dan pendidikan. Terdapat faktor demografi yang dapat memengaruhi kesejahteraan subjektif, yaitu: pendapatan, jenis 
kelamin dan pernikahan. Pendapatan menjadi hal utama yang sangat diperhatikan oleh individu khususnya dalam kehidupan.

\section{KAJIAN TEORI}

Hira dan Mugenda (1998) menyatakan bahwa kepuasan keuangan (financial satisfaction) mengacu pada komponen kesejahteraan finansial dimana terdapat evaluasi subjektif dari keadaan sumber daya keuangan seseorang yang memadai atau tidak memadai, maupun memuaskan atau tidak memuaskan. Berdasarkan pada pengertian sebelumnya bahwa untuk mencapai atau tidak mencapai kepuasan keuangan ditentukan melalui reaksi yang ditunjukkan pada suatu kejadian, mood yang dimiliki, dan penilaian terhadap kepuasan hidup.

Menurut Halim dan Astuti (2015), "Financial knowledge is the ability to understand, analyze and manage the finances to make the right financial decisions in order to avoid financial problems." Menurut Durband, Law, dan Mazzolini (2019), "Financial knowledge, in this sense, refers to a basic understanding of financial concepts and procedures as well as the use of this knowledge to to solve financial problems." Berdasarkan pada pernyataan sebelumnya disimpulkan bahwa pengetahuan keuangan merupakan pemahaman dasar mengenai konsep keuangan sehingga para individu dapat memahami, menganalisis, meguasai, dan mengelola keuangan dengan tepat serta efektif untuk memecahkan masalah keuangan.

Brandon dan Smith (2009) mengungkapkan bahwa efikasi keuangan (financial efficacy) merupakan adanya keyakinan positif terhadap kemampuan untuk mengelola uang dengan baik. Berdasarkan penelitian sebelumnya, semakin tinggi efikasi keuangan (financial efficacy) maka semakin tinggi juga dalam keyakinan untuk mengelola keuangan dengan tepat. Individu yang memiliki kekuatan atas keyakinannya terhadap kemampuan diri sendiri, maka individu tersebut dapat menjalankan suatu kegiatan yang penuh dengan tantangan dan memiliki keyakinan yang kuat terhadap kemampuannya untuk menyelesikan rintangan yang dimiliki serta mempunyai komitmen yang tinggi dalam mengelola keuangan di masa kini dan masa yang akan datang.

Menurut Falahati et al. (2012), childhood consumer experience merupakan pengalaman anak yang berhubungan dengan kegiatan keuangan yang diberikan oleh orang tua. Salah satu kegiatan yang dapat dilakukan yaitu adanya diskusi dengan orang tua mengenai finansial. Childhood consumer experience dapat diukur berdasarkan usia. Menurut Sabri, Cook, dan Gudmunson; Falahati et al. (2012), mengungkapkan bahwa pengalaman seorang anak yang diberikan oleh orang tua mengenai keuangan dapat didasari dengan adanya tabungan pribadi serta menerima uang jajan.

\section{Kaitan antara Financial Knowledge dan Financial Satisfaction}

Menurut Halim \& Astuti (2015); Dr. Selda Coşkuner (2016); Kumar Saurabh dan Tanuj Nandan (2018); serta Darmawan dan Pamungkas (2019) dalam penelitiannya menyatakan bahwa financial knowledge memiliki pengaruh positif dan signifikan terhadap financial satisfaction. Namun terdapat adanya pengecualian dalam satu studi penelitian yang dilakukan oleh O. Pratiwi (2019) yang menyatakan bahwa financial knowledge memiliki pengaruh yang tidak signifikan terhadap financial satisfaction. Serta Hira dan Mugenda (1998) juga menyatakan bahwa financial knowledge berpengaruh negatif terhadap financial satisfaction. Dimana disimpulkan bahwa individu yang memiliki financial knowledge yang tinggi akan menghasilkan penilaian status keuangan yang lebih ketat dan realistis, termasuk faktor-faktor negatif yang mempengaruhi persepsi status keuangan sehingga akan mempengaruhi financial satisfaction. 


\section{$\mathrm{H}_{1}$ : Financial Knowledge memiliki pengaruh terhadap Financial Satisfaction}

\section{Kaitan antara Financial Efficacy dan Financial Satisfaction}

Chatterjee, Finke, dan Harness (2011) dalam penelitiannya menyatakan bahwa efikasi keuangan merupakan prediktor suatu keinginan dalam melakukan investasi dan menjadi pendorong pada akumulasi aset keuangan yang dapat berpengaruh pada kepuasan keuangan. Dengan adanya efikasi keuangan yang mampu meningkatkan cara mengelola uang dengan tepat dan benar maka dapat menimbulkan peluang untuk memicu kepuasan keuangan. Berdasarkan penelitian sebelumnya, menunjukan sejalannya hasil dari penelitian yang dilakukan oleh Peter (2014) serta O. Pratiwi (2019) bahwa financial efficacy berpengaruh positif dan signifikan terhadap financial satisfaction.

\section{$\mathrm{H}_{2}$ : Financial Efficacy memiliki pengaruh terhadap Financial Satisfaction}

\section{Kaitan antara Childhood Consumer Experience dan Financial Satisfaction}

Childhood consumer experience dapat membantu anak untuk lebih mengatur pengelolaan keuangan dan mengambil keputusan yang tepat mengenai keuangan sehingga dapat berdampak pada kepuasan keuangan yang ingin dicapai. Pengelolaan keuangan yang baik akan berdampak baik pula terhadap kondisi keuangan, sehingga financial satisfaction terpenuhi (Falahati et al., 2012). Penelitian yang dilakukan oleh Falahati et al. (2012) juga memperoleh hasil bahwa childhood consumer experience berpengaruh positif dan signifikan terhadap financial satisfaction. Hal ini menunjukan adanya persamaan dalam hasil penelitian yang dilakukan oleh Candra \& Memarista (2015) bahwa Childhood consumer experience berpengaruh signifikan terhadap financial satisfaction. Tetapi, berbeda dengan penelitian yang dilakukan oleh Nidya Delvi Andini (2018) bahwa childhood consumer experience berpengaruh positif dan tidak signifikan terhadap financial satisfaction.

\section{$\mathrm{H}_{3}$ : Childhood Consumer Experience memiliki pengaruh terhadap Financial Satisfaction}

\section{METODOLOGI}

Populasi yang digunakan dalam penelitian ini merupakan Mahasiswa/i Universitas Tarumanagara. Dalam penelitian ini, peneliti akan menggunakan teknik pemilihan sampel non-probability sampling. Jenis non-probability sampling yang dipakai dalam penelitian ini yaitu purposive sampling. Purposive sampling merupakan sampel terbatas pada individu tertentu dimana mempunyai informasi yang diperlukan pada suatu penelitian (Sekaran dan Bougie, 2013:252). Dalam penelitian ini terdapat sampel sebanyak 150 responden dengan kriteria Mahasiswa/i aktif Universitas Tarumanagara yang kost di Jakarta Barat.

Operasionalisasi variabel bertujuan untuk mengidentifikasi variabel sesuai dengan kriteria yang diteliti. Dalam penelitian ini terdapat tiga variabel independen antara lain: financial knowledge, financial efficacy, dan childhood consumer experience. Sedangkan variabel dependen yang digunakan dalam penelitian ini adalah financial satisfaction. Variabel financial knowledge dalam penelitian ini akan diukur dengan menggunakan 4 indikator berdasarkan acuan dari Chen dan Volpe (1998). Selanjutnya, variabel financial self-efficacy dalam penelitian ini akan diukur dengan menggunakan 6 indikator berdasarkan acuan dari Lown (2011) dan Peter (2014). Lalu, pada variabel childhood consumer experience dalam penelitian ini akan diukur dengan menggunakan 3 indikator berdasarkan acuan dari Falahati 
et al. (2012). Kemudian, unutuk variabel financial satisfaction dalam penelitian ini akan diukur dengan menggunakan 6 indikator berdasarkan acuan dari Falahati et al. (2012) dan Hasibuan et al. (2018). Data yang digunakan dalam penelitian ini berdasarkan responden yang dituju sesuai dengan kriteria yang telah ditentukan dimana kuesioner ini dilakukan secara online melalui google form.

Pada inner model, nilai $R$-Square menurut Hair et. al (2014) hasil di atas 0,75 maka dikatakan kuat, sedangkan hasil di atas 0,50 dikatakan, dan hasil di atas 0,25 dikatakan lemah. Jika, nilai $Q^{2}>0$ menunjukan bahwa model tersebut mempunyai nilai relevansi prediksi, sedangkan nilai $Q^{2}<0$ menunjukan bahwa model kurang memiliki nilai relevansi prediksi (Hair et. al, 2014). Selanjutnya, nilai GoF dalam PLS terbagi menjadi tiga kategori, yaitu GoFsmall = 0,10, GoFmedium = 0,25, dan GoFlarge =0,36 (Wetzels et al., 2009). Pada $f^{2}$ hasil di atas $>0,02$ memiliki efek yang lemah, sedangkan hasil $>0,15$ memiliki efek yang sedang, dan hasil > 0,35 memiliki efek yang kuat (Garson, 2016). Nilai koefisien jalur distandarisasi pada rentang dari -1 hingga +1 , dengan nilai path coefficient yang lebih dekat ke +1 mewakili hubungan positif yang kuat, dan nilai path coefficient yang lebih dekat ke -1 menunjukkan hubungan negatif yang kuat (Hair et. al, 2014). Suatu hipotesis dapat dikatakan signifikan apabila p-value < 0,05 (Garson, 2016). Hipotesis penelitian dapat diterima, apabila nilai $t$-statistics lebih besar dari 1,96 jika nilai t-statistics kurang dari 1,96 maka hipotesis penelitian ditolak (Henseler et al., 2009; Hair et al., 2011). Kemudian, hipotesis dalam sebuah penelitian dapat dikatakan didukung apabila $P$-Value memiliki nilai kurang dari 0,05 (Garson, 2016). Alat yang digunakan untuk menganalisis data adalah dengan menggunakan PLS-SEM.

Dari 150 orang responden tersebut terdiri dari 67 orang $(44,7 \%)$ responden laki - laki dan 83 orang $(55,3 \%)$ responden perempuan. Selanjutnya, berdasarkan pada hasil deskripsi subyek penelitian mayoritas responden pada penelitian ini yaitu berasal dari jurusan Manajemen Bisnis. Untuk kategori angkatan, mayoritas atau yang paling mendominasi yaitu responden dengan angkatan 2017. Mayoritas responden juga telah kost selama 3 tahun. Untuk kategori pendapatan, mayoritas responden penelitian ini yaitu responden yang memperoleh pendapatan antara $\mathrm{Rp} 3.000 .001$ sampai $\mathrm{Rp}$ 4.000.000. Serta, mayoritas responden memperoleh pendapatan yang berasal dari orang tua.

\section{Analisis Validitas dan Reliabilitas}

\section{Analisis Validitas}

\section{a. Convergent Validity}

Menurut Henseler, Ringle dan Sinkovics (2009) convergent validity diuji dengan menggunakan acuan dari nilai outer loadings dari setiap indikator dimana suatu indikator dapat dikatakan valid apabila memiliki nilai outer loadings lebih dari 0,7. Terdapat ketentuan yang digunakan untuk menilai convergent validity yaitu melalui nilai dari average variance extracted (AVE). Berdasarkan penelitian sebelumnya, convergent validity dinyatakan sudah terpenuhi jika nilai average variance extracted (AVE) lebih dari 0,50.

Pada hasil penelitian diperoleh bahwa seluruh indikator yang digunakan memiliki outer loading factor lebih dari 0,7 yang mengartikan bahwa seluruh indikator pada penelitian ini valid secara konvergen (convergent validity). Selanjutnya, pada hasil analisis Average Variance Extracted ( $A V E$ ) seluruh variabel mamperoleh nilai lebih dari 0,5 yang berarti seluruh variabel pada penelitian ini dapat dinyatakan valid secara convergent validity.

\section{b. Discriminant Validity}

Dalam pemenuhan kriteria discriminant validity suatu indikator dapat dilihat dengan 
menggunakan analisis dari cross loading dan kriteria fornell-larcker. Menurut Henseller, Ringle \& Sarstedt (2015) nilai cross loading factor dapat memenuhi kriteria discriminant validity dengan membandingkan nilai cross loading pada setiap variabel memiliki nilai yang lebih besar dari variabel lainnya. Selain itu, metode analisis Fornell-Larcker pada discriminant validity dapat memenuhi kriteria apabila nilai akar kuadrat AVE untuk setiap variabel laten lebih besar dari korelasi antar variabel laten lainnya.

Berdasarkan hasil penelitian, nilai Cross Loading pada setiap indikator variabel financial knowledge, financial efficacy, childhood consumer experience, dan financial satisfaction memiliki nilai cross loading yang lebih besar jika dibandingkan dengan nilai cross loading indikator variabel lain. Sehingga, seluruh indikator tersebut telah memenuhi kriteria discriminant validity yang diukur dari nilai cross loading factor. Selanjutnya, pada nilai akar kuadrat AVE setiap variabel memperoleh hasil lebih besar dari korelasi antar variabel yang artinya telah memenuhi kriteria Fornell-Larcker pada discriminant validity, yaitu 0,816 (Financial Knowledge); 0,766 (Financial Efficacy); 0,848 (Childhood Consumer Experience); dan 0,769 (Financial Satisfaction).

\section{Analisis Reliabilitas}

Pengujian reliabilitas suatu instrumen dapat diketahui dari nilai Composite Reliability dan Cronbach's Alpha. Menurut Henseler, Ringle \& Sinkovics (2009) suatu variabel dinyatakan reliabel jika memiliki nilai Composite Reliability lebih besar dari 0,7. Menurut Malhotra (2010) suatu variabel dapat dikatakan reliabel apabila indikator mempunyai nilai Cronbrach's Alpha lebih besar dari 0,6. Pada nilai Composite Reliability dan nilai Cronbach's Alpha diperoleh melalui pengolahan data Software SmartPLS 3.3.3. Maka, dapat disimpulkan bahwa seluruh indikator yang digunakan oleh variabel laten pada penelitian ini dinyatakan reliabel karena menghasilkan nilai lebih besar dari 0,7 pada Composite Reliability dan menghasilkan nilai Cronbach's Alpha lebih besar dari 0,6 pada Cronbach's Alpha.

\section{ANALISIS DATA}

Berdasarkan hasil uji koefisien determinasi bahwa nilai ( $R$-Square) pada financial satisfaction yaitu sebesar 0,529 yang artinya tingkat kemampuan financial knowledge, financial efficacy, dan childhood consumer experience untuk menjelaskan financial satisfaction hanya sebesar 52,9\%. Sedangkan sisanya sebesar $47,1 \%$ dapat dijelaskan oleh variabel lainnya. Nilai ini dinyatakan tergolong sedang (moderate). Selanjutnya, pada hasil uji predictive relevance $\left(Q^{2}\right)$ yang diperoleh dengan menggunakan metode blindfolding yaitu sebesar 0,297 yang artinya hubungan konstruk variabel pada penelitian ini dinyatakan relevan karena nilai yang diperoleh lebih dari nol. Kemudian, pada nilai Goodness of Fit (GoF) penelitian ini dapat diperhitungkan secara manual dengan memasukkan nilai AVE dan nilai koefisien determinasi. Pada penelitian ini, nilai Goodness of Fit (GoF) yang diperoleh yaitu sebesar 0,584 dimana menunjukan bahwa model penelitian ini memiliki tingkat ketepatan yang tergolong besar (GoFlarge). Selanjutnya, hasil nilai $f$ square penelitian ini pada variabel financial knowledge memiliki efek yang kecil terhadap financial satisfaction yaitu sebesar 0,009 . Untuk variabel financial efficacy memiliki efek sedang (moderate) terhadap financial satisfaction yaitu sebesar 0,358. Lalu, variabel childhood consumer experience memiliki efek yang kecil terhadap financial satisfaction yaitu sebesar 0,061 .

Pada analisis uji hipotesis terdiri dari analisis jalur (path coefficient), $t$-statistics, dan analisis signifikansi (p-value). Dalam tabel 1 di bawah ini, dapat disimpulkan hasil dari uji hipotesis 1 menunjukkan bahwa financial knowledge memiliki pengaruh positif tetapi tidak 
signifikan. Selanjutnya, hasil dari uji hipotesis 2 menunjukkan bahwa financial efficacy memiliki pengaruh positif dan signifikan. Kemudian, hasil dari uji hipotesis 3 menunjukkan bahwa childhood consumer experience memiliki pengaruh positif dan signifikan.

Tabel 1

Hasil Pengujian Hipotesis

\begin{tabular}{|c|c|c|c|c|}
\hline Hipotesis & $\begin{array}{c}\text { Original } \\
\text { Sample }\end{array}$ & T-Statistics & P-Value & Keterangan \\
\hline $\begin{array}{c}\text { Financial Knowledge } \rightarrow \\
\text { Financial Satisfaction }\end{array}$ & 0,067 & 1,110 & 0,267 & Tidak Didukung \\
\hline $\begin{array}{c}\text { Financial Efficacy } \rightarrow \\
\text { Financial Satisfaction }\end{array}$ & 0,544 & 8,873 & 0,000 & Didukung \\
\hline $\begin{array}{c}\text { Childhood Consumer Experience } \rightarrow \\
\text { Financial Satisfaction }\end{array}$ & 0,220 & 3,329 & 0,001 & Didukung \\
\hline
\end{tabular}

Sumber: Hasil Olah Data Software SmartPLS 3.3.3

\section{DISKUSI}

Berdasarkan dari hasil uji hipotesis, terdapat satu hipotesis tidak didukung dan dua hipotesis didukung. Pada hipotesis pertama (H1) dinyatakan memiliki pengaruh positif tetapi tidak signifikan (tidak didukung). Hal ini menunjukkan bahwa semakin tinggi financial knowledge pada mahasiswa/i, belum tentu dapat mecapai financial satisfaction. Hasil ini selaras dengan hasil penelitian yang dilakukan oleh O. Pratiwi (2019) bahwa financial knowledge memiliki pengaruh positif tetapi tidak signifikan terhadap financial satisfaction dengan nilai $(\beta=0,009 ; p$-value $=0,161)$. Tetapi, hal ini tidak selaras dengan penelitian yang dilakukan oleh Kumar Saurabh dan Tanuj Nandan (2018) menyatakan bahwa financial knowledge memiliki pengaruh positif dan signifikan terhadap financial satisfaction yang berarti orang dengan financial knowledge tinggi cenderung puas dengan keadaan finansialnya karena lebih mengerti kondisi keuangan serta memahami cara mengatasinya. Hasil penelitian ini tidak sejalan juga dengan penelitian yang dilakukan oleh Dr. Selda Coşkuner (2016) bahwa tingkat financial knowledge yang tinggi dapat melakukan perencanaan investasi dan tabungan dengan lebih baik. Implikasinya adalah setiap individu perlu menyadari pentingnya memiliki pengetahuan keuangan yang baik agar mampu mengambil keputusan keuangan yang tepat untuk terhindar dari masalah keuangan.

Berdasarkan dari hasil uji hipotesis, pada hipotesis kedua (H2) dinyatakan memiliki pengaruh positif dan signifikan (didukung) karena memiliki nilai t-statistic lebih dari 1,96 dan nilai $p$-value kurang dari 0,05 . Hal ini sejalan dengan penelitian yang dilakukan oleh Peter (2014) bahwa individu yang memiliki financial efficacy tinggi dapat tercapainya kepuasan keuangan. Dengan demikian juga financial efficacy memiliki pengaruh positif dan signifikan terhadap financial satisfaction (O. Pratiwi, 2019). Oleh karena itu, hasil penelitian ini menunjukkan bahwa efikasi keuangan merupakan adanya keyakinan positif terhadap kemampuan untuk mengelola uang dengan baik (Brandon dan Smith, 2009). Kemudian, dengan diterimanya hipotesis ini artinya efikasi keuangan dapat terbentuk melalui 
pengelolaan keuangan. Hal tersebut menunjukan implikasi bahwa individu harus memiliki financial efficacy yang memadai agar memiliki tingkat kepuasan keuangan yang tinggi. Semakin baik dalam mengontol pemasukan dan pengeluaran setiap bulan secara disiplin maka dapat memicu untuk mencapai kepuasan keuangan semakin tinggi dimana mampu membeli barang yang diinginkan, memiliki tabungan untuk tujuan keuangan, dan mampu membayar tagihan.

Berdasarkan dari hasil uji hipotesis, pada hipotesis ketiga (H3) dinyatakan memiliki pengaruh secara positif dan signifikan (didukung). Hal ini menunjukkan bahwa semakin dini mahasiswa/i memperoleh pengalaman maka terdapat kemungkinan untuk mecapai financial satisfaction. Hasil ini sejalan dengan penelitian yang dilakukan oleh Falatahi et al. (2012); Candra \& Memarista (2015) bahwa childhood consumer experience berpengaruh positif dan signifikan terhadap financial satisfaction. Tetapi, hal ini tidak sejalan dengan penelitian yang dilakukan oleh Nidya Delvi Andini (2018) bahwa childhood consumer experience berpengaruh positif dan tidak signifikan terhadap financial satisfaction dengan nilai $(\beta=$ $0,006 ; p$-value $=0,921)$. Oleh karena itu, dengan diterimanya hipotesis ini maka menunjukan implikasi bahwa childhood consumer experience diperlukan dengan adanya diskusi mengenai keuangan yang diberikan oleh orang tua sejak dini sehingga dapat membantu anak untuk lebih mengatur pengelolaan keuangan dan mengambil keputusan dengan tepat sehingga berdampak pada kepuasan keuangan yang ingin dicapai. Pengalaman mengenai keuangan yang diberikan dapat diawali dengan memberikan uang saku kepada anak serta tabungan sebagai sarana dalam memulai pengelolaan keuangan dengan tepat yang bertujuan untuk memenuhi kebutuhan di masa datang baik dalam keadaan darurat ataupun tidak.

\section{KESIMPULAN}

Berdasarkan analisis dan pembahasan yang telah dijelaskan maka dapat disimpulkan bahwa hasil pada penelitian ini yaitu Financial Knowlede memiliki pengaruh positif tetapi tidak signifikan Financial Satisfaction. Sedangkan Financial Efficacy dan Childhood Consumer Experience memiliki pengaruh secara positif dan signifikan Financial Satisfaction.

Berdasarkan pada hasil penelitian yang telah diperoleh, maka peneliti dapat memberikan beberapa saran yang dapat bermanfaat baik bagi para pihak yang memiliki keterkaitan dengan penelitian ini serta peneliti selanjutnya yaitu, antara lain: Bagi Mahasiswa/i, disarankan untuk meningkatkan financial efficacy untuk mencapai financial satisfaction karena pada penelitian ini menyatakan bahwa financial efficacy memiliki pengaruh yang signifikan terhadap financial satisfaction. Dengan demikian, semakin tinggi efikasi keuangan pada mahasiswa maka dapat meningkatkan kepuasan keuangan. Bagi Orang Tua, disarankan untuk memberikan pengalaman mengenai keuangan sejak dini karena pada penelitan ini childhood consumer experience memiliki pengaruh yang signifikan terhadap financial satisfaction. Maka, semakin luas pengalaman mengenai keuangan yang diberikan oleh orang tua dapat meningkatkan tercapainya kepuasan keuangan pada anak di masa depan.

\section{DAFTAR PUSATA}

Andani, Nidya Delvi. (2018). Pengaruh Income, Financial Knowledge, Financial Behavior dan Childhood Consumer Experience Terhadap Financial Satisfaction Pada Pegawai 
PT. Perusahaan Listrik Negara (Persero) Wilayah Sumatera Utara. Univesitas Sumatera Utara.

Arifin, Agus Zainul. (2018). Influence Factors toward Financial Satisfaction with Financial Behavior as Intervening Variable on Jakarta Area Workforce. European Research Studies Journal. 21(1), 90-103.

Brandon, D. P. \& Smith, C. M. (2009). Prospective Teachers' Financial Knowledge and Teaching Self-Efficacy. Journal of Family \& Consumer Sciences Education, 27(1).

Candra, J. W., \& Memarista, G. (2015). Faktor-Faktor yang Mempengaruhi Financial Satisfaction pada Mahasiswa Universitas Kristen Petra. FINESTA, 3(2), 1-6.

Chen, H. \& Volpe, R.P. (1998). An Analysis of Personal Financial Literacy among College Students. Financial Services Review, 7(2), 107-128

Coşkuner, Selda. (2016). Understanding Factors Affecting Financial Satisfaction: The Influence of Financial Behavior, Financial Knowledge and Demographics. Imperial Journal of Interdisciplinary Research (IJIR), 2(5), 377-385.

Darmawan, D., \& Pamungkas, A. S. (2019). Pengaruh Financial Attitude, Financial Behavior, Dan Financial Knowledge Terhadap Financial Satisfaction. Journal of Economic, Management and Accounting, 2(2), 9.

Durband, D. B., Law, R. H., and Mazzolini, A. K. (2019). Financial Counseling. Springer Nature Switzerland AG 2019.

Falahati, L., Sabri, M. F., \& Paim, L. H. (2012). Assessment a model of financial satisfaction predictors: Examining the mediate effect of financial behavior and financial strain. World Applied Sciences Journal, 20(2), 190-197.

Fazli Sabri, M., Cook, C. C., \& Gudmunson, C. G. (2012). Financial well- being of Malaysian college students. Asian Education and Development Studies, 1(2), 153170.

Finke, Chatterjee, S, M. \& Harness, N. (2011). The impact of selfefficacy on wealth accumulation and portfolio choice. Applied Economics Letters. 18 (7), 627-631.

Garson, G. D. (2016). Partial Least Squares: Regression and Structural Equation Models. Asheboro, NC: Statistical Associates Publishers.

Hair Jr, J. F., Sarstedt, M., Hopkins, L., \& G. Kuppelwieser, V. (2014). Partial least squares structural equation modeling (PLS-SEM) An emerging tool in business research. European Business Review, 26(2), 106-121.

Halim, Yopie Kurnia Erista \& Astuti, Dewi. (2015). Financial Stressors, Financial Behavior, Risk Tolerance, Financial Solvency, Financial Knowledge, dan Kepuasan Finansial. FINESTA, 3(1), 19-23.

Henseler, J., Ringle, C. M., \& Sarstedt, M. (2015). A new criterion for assessing discriminant validity in variance-based structural equation modeling. Journal of the academy of marketing science, 43(1), 115-135

Henseler, J., Ringle, C. M., \& Sinkovics, R. R. (2009). The use of partial least squares path modeling in international marketing. In New challenges to international marketing. Emerald Group Publishing Limited.

Hira, T., \& Mugenda, O. (1998). Predictors of Financial Satisfaction: Differences Between Retirees and Non Retirees. Journal Financial Conseling and Planning, 9(2), 75-48.

Joe F. Hair, Christian M. Ringle \& Marko Sarstedt. (2011). PLS-SEM: Indeed a Silver Bullet. Journal of Marketing Theory and Practice 
Lown, J. M. (2011). Outstanding AFCPE® Conference Paper: Development and Validation of a Financial Self-Efficacy Scale. Journal of Financial Counseling and Planning, 22(2), 54-63.

Martin Wetzels, Gaby Odekerken-Schröder, Claudia van Oppen. (2009). Using PLS Path Modeling For Assessing Hierarchical Construct Models: Guidelines and Empirical Illustration. MIS Quarterly 33(1).

Pratiwi, O. (2019). Pengaruh Financial Knowledge, Financial Behavior, Financial Efficacy dan Risk Tolerance Terhadap Financial Satisfaction. Jurnal Dinamika Manajemen dan Bisnis, 2(2), 24-30

Sabri, M. F., Othman, M. A., Masud, J., Paim, L., MacDonald, M., \& Hira, T. K. (2008). Financial behavior and problems among college students in Malaysia: Research and education implication. Consumer Interest Annual, 54, 166-170

Saurabh, K., \& Nandan, T. (2018). Role of Financial Risk Attitude and Financial Behavior As Mediators In Financial Satisfaction. South Asian Journal of Business Studies, 7(2), 207-224.

Sina, P. (2014). Financial Efficacy dan Financial Satisfaction: Ditinjau dari Perbedaan Gender. Jurnal Manajemen Maranatha, 12(2).

Uma Sekaran and Roger Bougie. (2013). Research Methods for Business A Skill-Building Approach. Seventh edition.

White, A. G. (2007). A Global Projection of Subjective Well-being: A Challenge To Positive Psychology? Psychtalk 56, 17-20. 